DE

DE GRUYTER

OPEN

.
Journal of Intercultural Management

Vol. 7, No. 2, June 2015, pp. 75-88

10.1515/joim-2015-0011

Małgorzata Rozkwitalska ${ }^{23}$

Gdansk School of Banking

Ewa Magier-Łakomy ${ }^{24}$

Gdansk School of Banking

\title{
Does Country of Origin Matter whilst Evaluating Candidates for Managerial Positions?
}

Abstract: A growing number of foreign country nationals in economies worldwide challenges academics to raise a question whether one's country of origin (COO) matters when selecting candidates for managerial positions. Thus the aim of this paper is to analyze the $\mathrm{COO}$ effect on the evaluation of managerial competence of a foreign individual. The analysis includes both the literature review and the empirical findings from the authors' pilot research. A focus group interview is the method that was applied in the study. The analysis contributes to the nascent streams in international business and cross-cultural management research that concern the $\mathrm{COO}$ effect and the liability of foreignness (LOF) that refers to foreign newcomers (i.e. immigrants, ex/inpatriaties). It also adds some practical implications for the International Human Resource Management literature with that respect. The empirical findings suggest that $\mathrm{COO}$ is apparent when managerial skills are evaluated by locals.

Key words: country-of-origin effect (COO), competence evaluation, expatriates, immigrants, inpatriates, liability of foreignness (LOF), multinational corporations (MNCs), stereotypes

\footnotetext{
${ }^{23}$ mrozkwitalska@wsb.gda.pl

24 emagier@wsb.gda.pl
} 


\section{Introduction}

Several trends in the globalizing world economy have made the country-of-origin (COO) effect on the evaluation of managerial competence of a foreign individual a vital scientific inquiry. First, owing to new environmental complexities outside companies' home states, the demand for a more heterogonous staff with a broader knowledge base has resulted in an increase in the number of board members originating from different countries [van Veen et al., 2014]. As van Veen et al. [2014] posit, companies that expand abroad face a growing pressure to internalize the international aspects into their boards. Thus, they claim that COO of international board members matters and may impact on the company's performance. Second, for enterprises embedded in international markets, such as multinational corporations (MNCs), their effective functioning requires, among other issues, rational hiring expatriates or host country nationals to staff managerial positions in subsidiaries [Collings et al. 2007; Collings et al. 2008; Magier-Łakomy and Rozkwitalska 2013]. Third, the global mobility of workforce has led to the presence of immigrants and self-initiated expatriates in numerous economies, mainly developed ones [Collings et al. 2007; Nolan 2012; Samnani et al. 2012]. Fourth, the shortage of professionals who could fill certain key positions in organizations has compelled some industries, e.g. healthcare providers, to recruit foreigners, i.e. to attract immigrants [Harvey et al. 2004]. All the aforementioned trends show that the number of individuals with different nationalities and organizations in states has grown and will probably rise in the future. Hence, a study of the effect of $\mathrm{COO}$ on the evaluation of managerial competence of a foreign individual appears to be an appealing and promising academic inquiry that also fills a significant gap in the subject literature [MagierŁakomy and Rozkwitalska 2013; Rozkwitalska and Boguszewicz-Kreft 2014].

The paper, whose aim is to analyze whether COO affects the evaluation of managerial competence of a foreign individual, contributes to the nascent streams in international business and cross-cultural management research concerned with the $\mathrm{COO}$ effect and the liability of foreignness (LOF) that refer to foreign newcomers (i.e. immigrants, ex/inpatriaties). It also adds some practical implications for the International Human Resource Management literature with that respect.

The paper begins with the literature review that tackles on the COO effect and LOF issues. Afterwards, the research method and the empirical findings are discussed. Conclusions deal with contributions, practical implications and limitations of the analysis, which are subsequently followed by directions for future research.

\section{Literature review}

Although the country-of-origin effect, understood as an influence of the country of origin of products/brands/organizations on their perception by 
individuals [Ghazali et al. 2008], is relatively widely investigated in the international business literature [see e.g. Laroche et al. 2005; Lianxi et al. 2010; Balabanis and Diamantopoulos 2011], especially in the international marketing field, rather innumerous studies so far have tackled the problem of the COO effect of an overseas relocated individual and how it impacts on his/her quality perception by foreign locals. There are also two other streams of studies on the COO effect in international and intercultural management fields. The first stream of the research has mainly analyzed the COO effect as the extent to which practices of MNCs are embedded in their $\mathrm{COO}$, proving that MNCs from different countries behave in distinctive ways [see e.g. Noorderhaven and Harzing 2003; Ferner et al. 2001; Almond 2011]. The second, a recently emerging stream of the research, with some works directly stemming from the LOF studies, deals with the COO effect on the acceptance of foreign affiliates [Moeller et al. 2013] or foreigners by a host environment [Harvey et al. 2000; Harvey et al. 2005; Coates and Carr 2005; Joardar et al. 2007; Fang et al. 2013]. The latter stream offers understanding of the COO effect that is useful with regard to the aim of the paper since it looks at the COO effect as a specific predisposition to a given country, which results in a positive or negative attitude toward organizations and citizens from that state.

The above understanding of the COO effect can be conceptually referred to the LOF construct [Harvey et al. 2005; Moeller et al. 2013]. The LOF $^{25}$ was originally applied to the international business studies to explain obstacles faced by MNCs on international markets [Mezias 2002; Denk et al. 2012]. Nevertheless, later the construct was adjusted to reflect the challenges witnessed at the individual level by foreigners as well [Harvey et al. 2005; Moeller et al. 2013]. With that respect, it is assumed that foreignness may entail a liability, limiting the chance of possible success of foreigners in host economies. As Harvey et al. [2005] explain, foreignness transforms into a liability to managers from different cultures when they strive to build a professional or managerial role identity in their new country. Due to his/her COO, a relocated manager can be perceived by the locals as an out-group member and as such suffer from a lack of acceptance by the ones who perceive themselves as in-group members. Nationality is an obvious characteristic that causes subgroup identities and categorization. In congruence with social identity theory, host country nationals are more likely to demonstrate negative behaviors toward those assigned to their out-group and remain reluctant to work or foster the relationships with them, having a detrimental effect on their MNC [Joardar et al. 2007; Varma et al. 2006]. As a result, foreigners' COO may pose a stereotyping hazard [Fang et al. 2013].

${ }^{25}$ The liability - of foreignness of MNCs means overall, additional costs of operating abroad above the costs of domestic enterprises which function in a given market. These additional costs are the consequences of the spatial distance between the headquarters and its subsidiaries, a MNC's unfamiliarity with host-environments, a political and host-country risk and a lack of legitimacy among the locals [Mezias M.J. 2002; Denk N. et al 2012]. 
To the best of the authors' knowledge, only a few studies, to date, have investigated more or less explicitly the influence of $\mathrm{COO} / \mathrm{LOF}$ on the evaluation of the quality of foreigners. The examples of those works are summarized as follows.

Carr et al. [2001] have tested whether the COO effect can be noticed when candidates for various job positions are selected. Their study proved that the respondents revealed preferences for the locals (i.e. Tanzanian) over the expatriates. Nevertheless, for a job position where technical skills were a matter of importance, the respondents demonstrated preferences for expatriates from the West, since their technical skills were valued higher than the host country nationals' ones. Carr et al. also hypothesized, basing on social dominance theory, that foreign managers from a so-called dominant country would be favored as ex/inpatriates over other nationalities, who then may be challenged with biases regarding the evaluation of their professional competences. Hence, the study conducted by Carr et al. may suggest that the locals' mental hierarchies about $\mathrm{COO}$ affect the way they perceive foreign managers' competence.

Coates and Carr [2005] have studied job selection bias in the context of skilledimmigration in New Zealand. By referring to social dominance theory, social identity theory and the similarity-attraction paradigm, they explain the sources of selection bias among recruiters. They claim that organizations are inclined to homogeneity rather than diversity, therefore candidates perceived as dissimilar, e.g. due to their $\mathrm{COO}$, may experience selection bias in a recruitment process. Furthermore, individuals from less socio-economically dominant countries are likely to suffer from prejudice. Selection bias can also be observed with regard to neighboring countries. In their research, Coates and Carr [2005] corroborate that the perceived selection preferences are influenced by the COOs of immigrants, which implies that one's COO may impact on the assessment of someone's competence. Some subsequent studies that have been conducted in New Zealand and Australia also prove that Anglo-Saxon immigrants may be favored over others, i.e. from Asia and the Middle East [Ward 2008; Dandy and Pe-Pua 2010].

Another work by Harvey et al. [2005] is a good example of a theoretical study that provides a deep explanation on how stigmatization ${ }^{26}$ associated with the LOF ,and as a consequence of the COO effect, may affect the perception of the quality of inpatriates in MNCs. Harvey et al. identify four dimensions that impact on the acceptance of an inpatriate manager. They conclude that in order to recruit a proper inpatriate, i.e. accepted by the locals, MNCs should: 1) look for individuals who come from countries that in view of host locals have better quality managers than those available at home; 2) consider novelty of an inpatriate's COO, since it may affect the perception of his/her quality; 3) continually monitor the public opinion of a particular country because the opinion about managers from that country is

\footnotetext{
${ }^{26}$ A stigmatized individual may be stereotyped positively too [Harvey M. et al. 2005].
} 
subject to changes over time; 4) verify whether there is a general preference among MNCs' staff for home-country managers over inpatriates.

Magier-Lakomy and Rozkwitalska [2013] have elaborated on the previous studies with respect to immigrants, inpatriates and the acceptance of foreign affiliates and propose a model of COO impact on the evaluation of the quality of a manager. They indicate five moderators that determine relationships between the image of a country and the perception of a manager from that state, namely socio-economic dominance of a country, perception of the quality of a manager, novelty of COO, time and preferences for domestic managers. They have also empirically tested which countries' managers are perceived as the ones of high/low quality if the expected managerial effectiveness and strength differ depending on a manager's $\mathrm{COO}$ and whether domestic managers are favored over foreign managers. Their research shows a slightly privileged position of local managers over foreigners. It also proves that the expected managerial effectiveness and strength differ depending on a manager's $\mathrm{COO}$, suggesting that the $\mathrm{COO}$ effect is apparent when managerial competences are evaluated by the locals.

Van Veen et al. [2014] have scrutinized the COO composition of international board members from 15 European economies. They demonstrate that companies internationalize their boards in order to respond to the needs of the global economy. Nevertheless, to minimalize the risk of "fault-line settings when sub groups differ on a variety of demographic characteristics at the same time" [p. 408], companies recruit international board members that come from similar countries. Their research provides evidence that the $\mathrm{COO}$ of a board candidate matters and companies "tend to recruit international directors that are culturally, institutionally and geographically similar to the country where the company is situated" [p. 415]. Moreover, historical relations, e.g. the colonial past between states affect recruitment.

To summarize, the review of the prior works entitles to posit that the COO effect may be apparent when a managerial competence of a foreign manager is evaluated by the locals. First, it can be assumed that domestic managers will be preferred over foreigners. Second, within a group of foreigners those managers that come from socio-economically dominant countries are likely to be evaluated higher than others. Third, the novelty of a country will probably negatively influence the perception of a manager's quality, since a positive opinion is rather directed toward individuals from somewhat similar economies. Fourth, managers from some neighboring states may be assessed as worse ones by the locals.

The empirical verification of the aforementioned propositions is discussed in the following section of the paper. 


\section{Method and results}

\section{Research method and procedure}

The research was carried out as two focus group interviews at the end of the year 2013 and the beginning of the year 2015. It is continued, deepening the study carried out by Magier-Łakomy and Rozkwitalska [2013]. The focus group interview method was applied due to the explorative nature of the conducted study [Chan et al. 2012]. The participants of the first focus group (study A), consisting of 3 men and 4 women, part-time students, were all but one Poles. Except for 3 women, the remaining part of the group has worked for various, usually well-known MNCs. The participants of the second focus group (study B) were 12 part-time students, including 9 women and 3 men, all of Polish nationality. A half of the group has experience in working with foreigners in various types of organizations in Poland (including MNCs) or abroad. The subjects' age range in both focus groups was over 20 but less than 30 . The tape-recorded discussion was led by two moderators, the authors of the paper. In conformity with the procedure of carrying out a focus group interview [see e.g. Beyea and Nicoll 2000; Krueger and Casey 2008], the pre-determined questions were used for moderating the discussion concerning the COO effect on managerial competence evaluations while searching for an appropriate candidate for a managerial post. The way the questions were designed was partially inspired by the instrument developed by Carr et al. [2001] and Coates and Carr [2005].

Before discussing the COO effect, the participants were first asked several opening and generic questions regarding an ideal candidate's traits for a managerial position in MNCs, their experience of working under the supervision of a foreign manager and observed differences between managers from various countries. Consequently, in order to address the main topic, two exploration questions were asked, namely: 1) In your opinion, what countries educate the best managers?, and 2) Assuming that the only difference between the potential pool of candidates for a managerial position is their country of origin, who would you like to hire: a domestic manager or a foreigner? If a foreigner, what country should the manager come from and why? The collected recorded material was then transcribed and analyzed according to the discussed issues.

\section{Empirical findings}

During the first part of the discussion the participants listed several universal qualities that a good manager should have regardless of his/her level of managerial hierarchy, functional specialization or nationality. The subjects in study A commented on a manger's technical skills, such as an ability to divide tasks appropriately, an analytical mind and sufficient knowledge, as stated by a subject: 
"He needs to be in line with his business". Moreover, the participants emphasized some social skills of a good manager like taking responsibility for mutual effort, being supportive and encouraging, listening and being open to his/her employees' suggestions, ethical, providing equal treatment, recognizing a group dynamics and being a true member of a team. The participants of study B added to the list the following: ability to work under pressure, speaking languages, time management skills and open-mindedness.

With regard to the participants' experience of working under the supervision of a foreigner, they witnessed mainly positives of such a relation. An Israeli participant in study A reasoned that a foreigner is better integrated into a MNC and his/her presence in a subsidiary fosters learning opportunities: "My manager is more connected, let's say, than a local manager. (...) I give them (i.e. Polish employees) some knowledge that a Polish manager will not be able to get, because I come from a different environment. (...) They even said that they gained a lot of experience from me because I do the things differently and maybe I have a different set of skills than Polish ones." For another participant in study A the fact that the foreigner, who he 'had worked under' and who possessed some qualities of a good manager depicted earlier in the paper, contributed to the positive impression of such a cooperation. Some subjects in study B referred to a more open, friendly and people-oriented style of management of foreigners when compared to Poles: "I see differences in the approach to the employees". One of them also noticed that the Polish style of management, specifically in IT business, is changing in the same good direction and concluded that a specific style is determined by sector, country and personality.

The participants in both focus groups noticed or assumed that there were differences between managers from various countries. They provided examples which sometimes contradicted their observations of other people from the groups with regard to certain nationalities. Nevertheless, a lively discussion about the matter revealed that there were some countries which the participants associated with a lack of or poor managerial skills as well as nationalities that had a more positive connotation of a manger's quality. The participants were also directly asked what countries educated the worst managers and respectively, the best ones. The following states were mentioned in study A, i.e. with regard to the former: India, Singapore, Italy and Poland, and considering the latter: Belgium, the Netherlands and the United Kingdom. The opinions among the participants in study B were more inconsistent. For example, Poland was perceived by some of the participants as a country with poorly qualified managers, while the others considered Polish managers as one of the best: "We look too much to the West. (...) Leadership there (i.e. Poland, India, China) is at a very high level". The other states that were associated with a positive managerial education were Germany, the United States, the United 
Kingdom, and Scandinavian countries, while France, Italy, Spain, Greece and some post-Soviet countries (e.g. Croatia, Bulgaria) with a rather poor educational system with respect to managers. In general, the participants' preferences were determined by socio-economic dominance of a country: "German economy is on the first spot and it is an effect of something."; "Looking at their economy, if they had good managers, their economy would stand better."

One of the subjects in study A remarked that there should be a necessity to consider the desired attributes of a manager from the point of view of tasks' requirements and then analyze them referring to certain typical countries' characteristics: "From my point of view, it depends on what you expect from your manager and then you can define the best one. If you want a friendly and decent, who always tells you the truth, Belgians, the Dutch, Nordics are good (...). If you want the job to be done, the ones from the UK, the US and Israel are the best. If you want very structured things, find the Germans. (...) If you care about deadlines, you won't question anything, go to Asian." This part of the discussion also discovered widely shared stereotypes among the group members who were assigning some expected traits to different nationalities, not always basing on their personal experience.

In study A the authors collected the congruent opinions concerning preferences for hiring foreigners. The participants provided several complementing explanations: "I want different opinions. I don't want to stick to a single point. Diversity is very important (...). A manager from Italy, Germany and Poland, there are three different opinions to see the same thing. (...) If I have five Poles, I need someone from abroad."; "(...) it is an opportunity to work with people who are not similar"; "When we have a foreign manager, we can expect our future in the world, e.g. we are not so closed in our country, we look out of the borders, we get knowledge from different countries, we are more open, it's important to find out different things."

In contrast to the above results, in study B the majority of the subjects exposed a general preference for hiring local managers and reasoned it as follows: "Poles - easy to work with, a lack of creed or cultural barriers."; "Simply, patriotism. (...) A Pole is here, I don't need to relocate him. (...) a lack of formal and language barriers." Some participants particularly stressed that the legal environment in Poland is subject to constant changes and it is difficult to cope with the excessive red tape while employing foreigners. It puts extra effort for both the employee and the employer: "An employee's effectiveness will be lower". Yet, one of the participants opted for a German manager as a person who presumably is well-organized, and another one could accept someone from abroad to challenge the stereotypes about Polish xenophobia, while still preferring Poles. Nonetheless, the participants also remarked that a company's orientation may be a decisive factor, i.e. a firm with a domestic orientation should look for local managers whilst an enterprise that 
wants to operate internationally needs a more internationalized staff. The current political situation with neighboring countries and behaviors of immigrants also affected the opinions of the participants. Moreover, the subjects' preferences were rather directed to some culturally better recognized countries: "We don't know the country, so it's hard to comment on that" ${ }^{\prime 2}$.

It needs to be stressed that the participants of both focus groups did not want to directly acknowledge the importance of managers' $\mathrm{COO}$ in their selection decisions that concerned hiring a potential candidate. They rather ascertained that such a decision had to be based on more accurate data collected via an interview as well as such a crucial factor as a match between the candidate's skills and the job's requirements: "You must interview them."; "You can't choose basing on the paper."; "You don't need to question about the flag on their chests, for me, we should question if they are the best man for a job, that's it." Despite the participants' declarations, when they were compelled by the moderators to make a choice within a potential pool of candidates and to disclose who they would like to exclude from the hiring list, the following statements appeared in study A: "I would not hire Italians, overall. (...) I would rather hire someone from Israel, the UK, Germany (skipping France), Belgium, the US. (...) I would probably skip Poles."; "I would skip Italian ones, maybe they are very stylish, they provide you with the best looking digits... . but their maniana style does not appeal to me. I guess I would go for Brits (...)."; "I would exclude Germans and Poles."; "I would exclude an Irish, there is no way to communicate with Irish people."; "I would exclude Scottish ones."; "I have experience only with Polish managers, so definitely not Poles."; "Spanish managers are not good." The foregoing remarks may suggest that the COO of a candidate is a matter of significance when the qualifications of a candidate manager are evaluated, even if the focus groups' members did not want to directly admit the fact. Furthermore, another participant in study A recommended matching the requirements of a job with a country's population's typical characteristics while deciding what nation would fit the best. The subjects in study B would not invite to interviews candidates from Greece (due to its economic problems), Arabic and African countries and others which they knew less.

Taking into account the collected data, it can be summarized as follows: 1) The participants were able to draw a universal picture of an ideal manager; 2) They would assumably prefer to work with the nationalities that have some qualities of a good manager; 3) They were aware of some cultural differences among countries that may be found in management styles. Concerning the COO effect, it can be noticed that:1) The participants in study A revealed preferences towards foreign

${ }^{27}$ The possible methodological and theoretical explanation of the observed difference between these two focus groups with respect to the empirical findings concerning domestic managers, obtained despite taking the samples from the same population, is given in 'Discussion and conclusions' section. 
managers, while in study B favored domestic managers; 5) The degree of socioeconomic dominance of a country as well as its novelty may affect the perception of managers' quality from that state; 6) Managers from some neighboring countries may be evaluated worse than others. The assessment is likely to be affected by a current political situation and historical relations. 7) There were some discrepancies between the focus group members' declarations and their anticipated decisions referring to their selection choices, which may result from the differences between the participants' implicit and explicit attitudes.

The obtained data from the focus group interviews confirmed that the COO effect is apparent when managerial skills are evaluated by the locals.

\section{Discussion and conclusions}

The main aim of the discourse was to analyze whether COO may affect the evaluation of managerial competence of a foreign individual. It has been revealed that the COO effect has been relatively widely investigated in the extant literature and research, yet most of the previous works define the COO effect in terms of product-buyer perception. In this paper the authors analyze the COO impact on the evaluation of managerial competences to fill in the obvious gap in the state-of-theart knowledge of $\mathrm{COO}$ and to shed a new light on it. Hence, the major contribution of the conducted study is the investigation of the COO effect in a new context of managerial competences evaluation. The study supports the nascent streams in international business and cross-cultural management research on the COO effect and the $\mathrm{LOF}$ that refer to immigrants and ex/inpatriaties. The practical implication of the study is that companies should take into account how the COO of a manager may affect the perception of his/her competence while searching for an appropriate candidate. Human Resource specialists need to be aware that mental hierarchies concerning the $\mathrm{COO}$ of a candidate impact on their choices and that the $\mathrm{COO}$ of a selected manager can influence ease or difficulty witnessed in the process of his/ her adaptation to the firm.

Taking into account the empirical findings, the COO effect is apparent when managerial skills are evaluated by the locals. The authors' research confirms the results of the prior studies with respect to preferences for individuals from culturally less distant and novel countries and socio-economically dominant states. Similarly to Coates and Carr [2005], managerial candidates from some neighboring countries (in the East) were less preferred than those from the West, which can be explained by a current political situation, historical relations as well as dominance of the West in the global economy. Some stereotyped cultural characteristics of an expected managerial style in a given country can also affect the preferences. Managers from West and North Europe and North America were favored over candidates from the East and the South. 
The inconclusive results were obtained with regard to the preference for domestic managers. One of the possible explanations for that inconsistency can be referred to the methodological issue of the study. The samples for both focus groups were taken from the same population and they were similar in terms of demographical variables, yet with one exception that could be significant, namely there was a foreigner in group A and only Poles in group B. The presence of the foreigner in the focus group interview might have triggered two separate mechanisms: the cognitive or/and the social one. Due to the cognitive architecture of the human mind [Anderson 1983], the friendly foreigner's presence could have automatically (involuntarily) activated in the subjects' mind a new category associated with a social exchange which led people to specific cooperative behavior and declarations. As far as the social mechanism is concerned, the presence of the foreigner might have switched on someone's self-control mechanism and revealed social desirability bias, i.e. a tendency to present oneself in a positive, socially desirable manner to others [Collins et al. 2015]. Hence, the participants in study A could have been more aware that exposing preferences for local managers violate the rule of being open-minded, cooperative, objective, etc. and then they could have been taken as being intolerant. Owing to the research method applied to the study, it is difficult to conclude which of the mechanisms affected the results or whether both of them were evident. The authors are aware that the focus group method per se may increase social desirability bias, i.e. in the course of the focus group discussion the participants could have tried to portrait themselves as people who were not biased towards certain nationalities (i.e. the COO of a potential manager). Due to the qualitative method applied to the research, excluding or controlling social desirability bias was limited. Thus further study should respond to this issue, being, e.g. carried out as a set of controlled experiments.

Taking into account the results in study B, it may also be of vital importance to analyze in future research how strongly administrative barriers impede employment of foreigners and when the potential positives of hiring someone of another nationality surmount those barriers. For instance, do we only need foreign managers in MNCs' subsidiaries or companies that want to expand abroad? Can foreign managers enhance the domestic business as well?

The conducted research was obviously explorative and pilot in nature, thus additional studies are necessary. The participants of the focus groups were young adults with a diverse degree of work experience, especially with foreigners. These factors could have affected their remarks. Therefore, further research could be conducted among more professionally and cross-culturally experienced people and have a form of a comparative analysis within the groups mentioned above. Since all but one of the subjects were Poles, a generalization to other cultures is limited. Hence, future research may be extended to other nationalities and conducted as 
a comparative study. The research was to obtain opinions on the issue and it only discovered the declared attitudes of the participants, which may run counter to their implicit attitudes [Greenwald 1995]. Consequently, some additional research methods could be applied in order to scrutinize implicit attitudes of respondents.

\section{Bibliography}

Almond P. (2011), Re-visiting 'country of origin' effects on HRM in multinational corporations, "Human Resource Management Journal”, Vol. 21 No. 3, pp. 258-271.

Anderson J.R. (1983), The Architecture of Cognition, Harvard University Press, Cambridge, MA.

Balabanis G., Diamantopoulos A. (2011), Gains and losses from the misperception of brand origin: The role of brand strength and country-of-origin image, "Journal of International Marketing", Vol. 19, No. 2, pp. 95-115.

Carr S.C., Rugimbana R.O., Walkom E., Bolitho F.H. (2001), Selecting expatriates in developing areas: 'country-of-origin' effects in Tanzania?, "International Journal of Intercultural Relations", Vol. 25, No. 4, pp. 441-457.

Chan Y.I.S., Leung M., Shi S., Yu W. (2012), Managing the stress of Hong Kong expatriate construction professionals in Mainland China: Focus group study exploring individual coping strategies and organizational support, No. October, pp. 1150-1161.

Coates K., Carr S.C. (2005), Skilled immigrants and selection bias: A theory-based field study from New Zealand, "International Journal of Intercultural Relations", Vol. 29, No. 5, pp. 577599.

Collings D.G., Morley M.J., Gunnigle P. (2008), Composing the top management team in the international subsidiary: Qualitative evidence on international staffing in U.S. MNCs in the Republic of Ireland, "Journal of World Business", Vol. 43, No. 2, pp. 197-212.

Collings D.G., Scullion H., Morley M.J. (2007), Changing patterns of global staffing in the multinational enterprise: Challenges to the conventional expatriate assignment and emerging alternatives, "Journal of World Business", Vol. 42 No. 2, pp. 198-213.

Collins S.E., Grazioli V.S., Torres N.I., Taylor E.M., Jones C.B., Hoffman G.E., Haelsig L. et al. (2015), Qualitatively and quantitatively evaluating harm-reduction goal setting among chronically homeless individuals with alcohol dependence, "Addictive Behaviors", Elsevier Ltd, Vol. 45, pp. 184-190.

Dandy, J. and Pe-Pua, R. (2010), Attitudes to multiculturalism, immigration and cultural diversity: Comparison of dominant and non-dominant groups in three Australian states, "International Journal of Intercultural Relations", Vol. 34, No. 1, pp. 34-46.

Denk N., Kaufmann L., Roesch J.-F. (2012), Liabilities of foreignness revisited: A review of contemporary studies and recommendations for future research, "Journal of International Management", Elsevier Inc., Vol. 18, No. 4, pp. 322-334.

Fang T., Samnani A.-K., Novicevic M.M., Bing M.N. (2013), Liability-of-foreignness effects on job success of immigrant job seekers, "Journal of World Business", Elsevier Inc., Vol. 48, No. 1, pp. 98-109. 
Ferner A., Quintanillab J., Varulc M.Z. (2001), Country-of-origin effects, and the management of HR in multinationals: German companies in Britain and Spain, "Journal of World Business", Vol. 36 No. 2, pp. 107-127.

Ghazali M., Othman M.S., Zahiruddin A., Ibrahim M.S. (2008), Products and country of origin effects: The Malaysian consumers' perception, "International Review of Business Research Papers", Vol. 4, No. 2, pp. 91-102.

Greenwald B. (1995), Implicit social cognition-attitudes, self-esteem, and stereotypes, "Psychological Review", Vol. 102, No. 1, pp. 4-27.

Harvey M., Hartnell C., Novicevic M. (2004), The inpatriation of foreign healthcare workers: A potential remedy for the chronic shortage of professional staff, "International Journal of Intercultural Relations", Vol. 28, pp. 127-150.

Harvey M., Novicevic M.M., Buckley M.R., Fung H. (2005), Reducing inpatriate managers' 'Liability of Foreignness' by addressing stigmatization and stereotype threats, "Journal of World Business", Vol. 40, No. 3, pp. 267-280.

Harvey M., Ralston D., Napier N. (2000), International relocation of inpatriate managers: assessing and facilitating acceptance in the headquarters organization, "International Journal of Intercultural Relations", Vol. 24, No. 6, pp. 825-846.

Joardar A., Kostova T., Ravlin E.C. (2007), An experimental study of the acceptance of a foreign newcomer into a workgroup, "Journal of International Management", Vol. 13, No. 4, pp. $513-537$.

Krueger R.A., Casey M.A. (2008), Focus Groups: A Practical Guide for Applied Research, Sage Publications, New York, 4thed.

Laroche M., Papadopoulos N., Heslop L.A., Mourali M. (2005), The influence of country image structure on consumer evaluations of foreign products, "International Marketing Review", Vol. 22, No. 1, pp. 96-115.

Lianxi Z., Yang Z., Hui M.K. (2010), Non-local or local brands? A multi-level investigation into confidence in brand origin identification and its strategic implications, "Journal of the Academy of Marketing Science”, Vol. 38, No. 2, pp. 202-218.

Magier-Lakomy E., Rozkwitalska M. (2013), Country-of-origin effect on manager's competence evaluations, "Journal of Intercultural Management”, Vol. 5, No. 4, pp. 5-21.

Mezias J.M. (2002), How to identify liabilities of foreignness and assess their effects on multinational corporations, "Journal of International Management”, Vol. 8, No. 3, pp. 265-282.

Moeller M., Harvey M., Griffith D., Richey G. (2013), The impact of country-of-origin on the acceptance of foreign subsidiaries in host countries: An examination of the liability-of-foreignness, "International Business Review”, Elsevier Ltd, Vol. 22, No. 1, pp. 89-99.

Nolan S. (2012), Global mobility of human capital increasingly important, "Strategic HR Review", Vol. 11, No. 3.

Rozkwitalska M., Boguszewicz-Kreft M. (2014), Efekt kraju pochodzenia a funkcjonowanie przedsiebiorstw wielonarodowych - analiza koncepcji, "Marketing i Rynek", Vol. 5, pp. 557-564. 
Samnani A.-K., Boekhorst J.A., Harrison J.A. (2012), Acculturation strategy and individual outcomes: Cultural diversity implications for human resource management, "Human Resource Management Review", Elsevier Inc., Vol. 22 No. 4, pp. 323-335.

Varma A., Toh S.M., Budhwar P. (2006), A new perspective on the female expatriate experience: The role of host country national categorization, "Journal of World Business", Vol. 41, pp. 112-120.

Van Veen K., Sahib P.R., Aangeenbrug E. (2014), Where do international board members come from? Country-level antecedents of international board member selection in European boards, "International Business Review", Elsevier Ltd, Vol. 23 No. 2, pp. 407-417.

Ward C. (2008), Thinking outside the Berry boxes: New perspectives on identity, acculturation and intercultural relations, "International Journal of Intercultural Relations", available at: http://www. sciencedirect.com/science/article/pii/S0147176707000855 (accessed 23 March 2015). 